\title{
Numerical Modeling of Structural Irregularities on Unsymmetrical Buildings
}

\author{
Halil Ibrahim BURGAN
}

\begin{abstract}
Since the formation of the world, it is known that the earthquakes in seismic-active regions are occurring in sequences and from their results there are losses to millions of people and buildings. As Turkey is located in one of the world's most active seismic zones there are many studies for minimizing the damages especially at buildings during earthquakes. In this study, the seismic analyses were handled for a 10-storey unsymmetrical (L-shaped) building according to the Turkish Earthquake Code (TEC). These analyses contain the controls of A1-torsional irregularity, B2-weak-storey irregularity, relative storey displacements and second order effects. Furthermore, due to the lack of symmetry of the building, model was analysed for both $+X$ and $+Y$ directions. In order to correct irregularities which would occur in building models, the shear walls will be placed in different $+X$ and $+Y$ axles and positions and the analyses were repeated. According to the results for the case of an earthquake the safest and the most economical building model was suggested. Loads in all analyses in the study were calculated using "Equivalent Earthquake Loading Method" stated in TEC. The results will reveal a new look especially in the earthquake engineering.
\end{abstract}

Keywords: equivalent earthquake loading (EEL) method; numerical modelling; shear walls; TEC; torsional irregularity; weak-storey irregularity

\section{INTRODUCTION}

Since the formation of the world, it is known that the earthquakes in seismic-active regions were occurring in sequences and from their results millions of people and shelters were damaged. There are studies on earthquake estimation and modelling by civil, geological and geophysical engineering disciplines. For this aim, required data can be taken from related departments such as seismological bureaux in countries, United States Geological Survey (USGS) [1]. Turkey is located in one of the world's most active earthquake zones. In the past, there were several devastating earthquakes in Turkey, so it is real that many properties and lives can be damaged and destroyed by earthquakes.

According to maps of earthquake zones, it is known that $92 \%$ of Turkey is in the earthquake zones, $95 \%$ of population lives under the threat of earthquakes, $98 \%$ of large industrial centres and $93 \%$ of dams are located in earthquake zones. The Erzincan, Ceyhan, Izmit, Duzce and Afyon earthquakes (between years 1992-2003 and magnitudes 6.3-7.4) are the most destructive earthquakes of Turkey in the last 14 years [2]. Due to the earthquakes in the last 58 years, 58202 people lost their lives, 122096 people were injured and nearly 411465 buildings were destroyed or severely damaged. So nearly 1003 people died and 7094 buildings were destroyed every year in Turkey because of earthquakes.

Tall buildings can be affected by horizontal forces such as wind and earthquake. Nevertheless, horizontal load systems for tall buildings are developed. Generally, improper applications are causing the formation of various irregularities on structures. Also, unforeseeable results can be monitored especially on unsymmetrical buildings with different loads. It is a very important issue that the seismic performance decline of the buildings based on structural irregularities as weak-storey irregularity, torsional irregularity etc., [3].

The irregularities on structures should be taken into consideration at the preliminary design stage [4]. Also, pushover analysis should be both in $+X$ and $+Y$ directions [5]. Because the structure under earthquake loads can be demonstrated different reactions against earthquake loads from different directions. Software as ETABS, SAP2000, MIDAS/GEN, SATWE etc. can be widely used in the structural analysis [6]. TEC is taken into consideration for the displacement limits as in the case of Acun \& Sucuoglu (2011). Soyluk \& Tuna (2011) checked irregularities according to TEC $[7,8]$. It is known that after construction, the rehabilitation or restoration procedures of the building are not easy for application, also they have high costs. In some cases, reconstruction process may be required. A lot of studies are available about strengthening conducted on elements of load-carrying system such as beam, column etc., [9].

It is known that the optimization is required between safety and economical engineering design considering earthquake effects. In this study, torsional irregularity was handled due to its significance on unsymmetrical building during earthquake loads. The studies about torsional effects on buildings during earthquake were started before 1980s [10]. The seismic performances of the irregular structures were evaluated in this scope [11]. Also, some computer programs as DURTES can be used for the rapid estimation of the buildings for potential seismic hazard [12]. Additionally, new materials as geopolymer can be assessed in construction projects [13]. There are some national building codes under earthquake loads to construct buildings in the countries as Bulgaria [14].

The earthquake loads on buildings should be considered in detail. Earthquake codes as The European seismic code 8 (Eurocode 8) classify structures by some criteria as eccentricity, torsional radius and stiffness. Especially, torsional irregularity effects cannot be fixed after real earthquake loads, so the subject is still hot. There are new studies on torsional provisions [15-18]. Also, Structural Equation Modeling (SEM) can be applied after static and dynamic load calculations [19].

Shear walls can change the behaviour of the building during earthquake. Structural analyses were evaluated before considering shear walls in terms of irregularity controls [20]. The regulations of TEC for shear walls were interpreted with definitions of minimum dimensions of shear walls [21]. Although there are studies about steel shear walls [22], the studies on reinforced concrete shear walls under earthquake loads are limited. 
The novelty of this study is investigation of torsional irregularity effects on an L-shaped unsymmetrical building. The calculations are made in SAP2000 software and some design criteria are evaluated. As a solution, shear wall positions are assessed in the study.

\section{MATERIALS AND METHODS}

The methods of seismic analysis on buildings are Equivalent Earthquake Loading Method, Modal Analysis and Analysis Method in Time Domain. Modal Analysis and Analysis Method in Time Domain can be used in seismic analysis in every type of building without any limitations. But there are some limitations for EEL method in TEC [23]. In this study, EEL method was used for seismic analysis, so the methodology and details of EEL method are presented. The units in the paper are " $m$ " as displacement \& height, " $t$ " as weight \& load and " $s "$ as time. Any other coefficients and factors are dimensionless.

\subsection{EEL Method}

It is known that the earthquake load affects mass centre of the building. But, resistance force affects the centre of rigidity of the building. The torsional irregularity is arising from conflicting mass centre and rigidity centre points. In this way, tremendous torsional moments will happen if there is difference of space between these two points.

Total Equivalent Earthquake Load $V_{t}$ affects the whole building in earthquake direction. And it can be calculated as

$V_{t}=\frac{W A\left(T_{1}\right)}{R_{a} A\left(T_{1}\right)} \geq 0.10 A_{0} I W$

where, $A(T)$ is the spectral acceleration coefficient, $A_{0}$ is the effective ground acceleration coefficient, $I$ is the building importance factor, $R_{a}\left(T_{1}\right)$ is the ductility factor and $W$ is the total weight of the building using the moving load contribution coefficient. Here, $T_{1}$ is the first natural vibration period of the building.

$T_{1}=2 \pi\left(\frac{\sum_{i=1}^{N} m_{i} d_{\mathrm{f} i}^{2}}{\sum_{i=1}^{N} F_{\mathrm{f} i} d_{\mathrm{f} i}}\right)^{1 / 2} \rightarrow\left(F_{f i}=\frac{w_{i} H_{i}}{\sum_{j=1}^{N} w_{j} H_{j}}\right)$

where, $m_{i}$ is the mass of the $i^{\text {th }}$ storey, $d_{\mathrm{f} i}$ is the calculated displacement with $F_{\mathrm{f} i}$ fictive load on the $i^{\text {th }}$ storey, $N$ is the highest storey. $F_{\mathrm{fi}}$ is fictive load which affects the $i^{\text {th }}$ storey, and it is determined as any value (e.g. unit value) instead of $V_{t}-\Delta F_{N}\left(\Delta F_{N}\right.$ is the additional equivalent earthquake load which acts on the highest storey). Here, $w_{i}$ is the weight of the $i^{\text {th }}$ storey, $H_{i}$ is the height measured from the base of the first storey of the building. The total weight $W$ of the building which will be used for the calculation of seismic loads,

$$
W=\sum_{i=1}^{N} w_{i} \quad \rightarrow \quad\left(w_{i}=g_{i}+n . q_{i}\right)
$$

where, $g_{i}$ is the constant load of the $i^{\text {th }}$ storey, $q_{i}$ is the moving load of the $i^{\text {th }}$ storey, $n$ is the moving load participation factor. In this study, moving load participation factor $\mathrm{n}$ was selected as 0.30 , because the model was considered as housing. But other studies $\mathrm{n}$ can be selected until 0.80 value according to importance degree and purpose of buildings (e.g. school, hospital, storage, etc.).

\subsection{Calculation of Equivalent Earthquake Loads Effects on Each Storey}

Total Equivalent Earthquake Load which was calculated from Eq. (1), was expressed as sum of Equivalent Earthquake Loads,

$V_{t}=\Delta F_{N}+\sum_{i=1}^{N} F_{i} \quad \rightarrow \quad\left(\Delta F_{N}=0.0075 N V_{t}\right)$

where, $F_{i}$ is the equivalent earthquake load of the $i^{\text {th }}$ storey with EEL method. Extra Equivalent Earthquake Load $\Delta F_{N}$ is enforced on $N^{\text {th }}$ (the highest) storey and it can be calculated from Eq. (5). The rest of Total Equivalent Earthquake Load, except $\Delta F_{N}$, but including $N^{\text {th }}$ storey, will be distributed to storeys of building model.

$$
F_{i}=\left(V_{t}-\Delta F_{N}\right) \frac{w_{i} H_{i}}{\sum_{j=1}^{N} w_{j} H_{j}}
$$

If there is A1 type torsional irregularity on any $i^{\text {th }}$ storey, providing $1.2<\eta_{k i} \leq 2.0, \pm 5 \%$ additional eccentricity which is applied on the storey, for two earthquake directions, will be raised by multiplying $D_{i}$ coefficient (Fig. 1). $\eta_{k i}$ is the torsional irregularity coefficient on the $i^{\text {th }}$ storey [24]. B and e lengths are lengths of storey side and distance between acting-center points, respectively.

$$
D_{i}=\left(\frac{\eta_{k i}}{1.2}\right)^{2}
$$

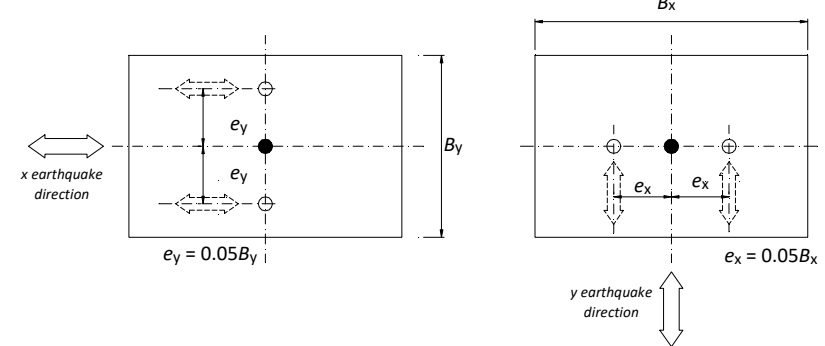

Figure 1 Acting points of earthquake loads for $x$ and $y$ directions

If torsional irregularity was not considered, the earthquake would be affected on the unsymmetrical building more devastating. The joints were assessed before under torsional load by numerical solutions [25]. 


\section{APPLICATION OF THE METHOD}

The plan (Fig. 2a) of the storey and information about the building is given below. 10-storey building with 3.50 $\mathrm{m}$ storey heights has no basement and building importance factor is selected as 1 . Cast in place reinforced concrete frame systems is the type of structural system. Earthquake zone is 1 and Effective ground acceleration coefficient $\left(A_{0}\right)$ is 0.40 . Local soil type is $\mathrm{Z} 3$ with $T A=0.15$ and $T B=0.60$ spectrum characteristic periods. Finally, structural system behaviour coefficient is selected as 8 . The natural vibration period of the building is calculated as $1.472 \mathrm{~s}$ from Tab. 1.

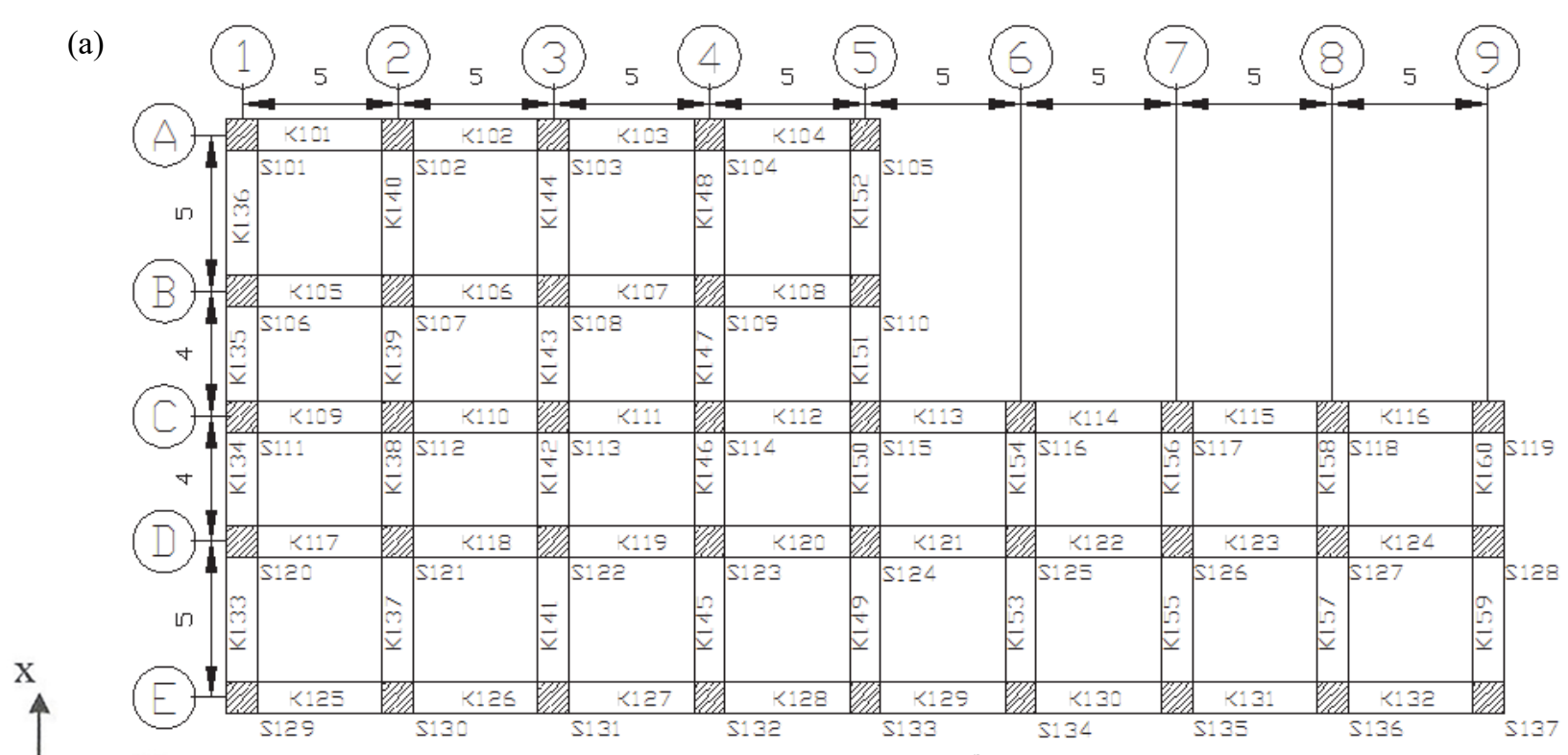

(b)

Figure 2 (a) The plan of the model; (b) The perspective view of the best suggested model with shear walls by two sides

Table 1 Calculation of natural vibration period of the building

\begin{tabular}{|c|c|c|c|c|c|}
\hline Storey No. & $m_{i}$ & $F_{\mathrm{fi}}$ & $d_{\mathrm{fi}}$ & $m_{i} \cdot d_{\mathrm{fi}}{ }^{2}$ & $F_{\mathrm{fi}} \cdot d_{\mathrm{fi}}$ \\
\hline 10 & 45.235 & 0.1818 & 0.0001575 & 0.000001122 & 0.0000002 \\
\hline 9 & 45.235 & 0.1636 & 0.0001478 & 0.000000988 & 0.0000242 \\
\hline 8 & 45.235 & 0.1455 & 0.0001348 & 0.000000822 & 0.0000196 \\
\hline 7 & 45.235 & 0.1273 & 0.0001189 & 0.000000640 & 0.0000151 \\
\hline 6 & 45.235 & 0.1091 & 0.0001005 & 0.000000457 & 0.0000110 \\
\hline 5 & 45.235 & 0.0909 & 0.0000800 & 0.000000290 & 0.0000073 \\
\hline 4 & 45.235 & 0.0727 & 0.0000800 & 0.000000290 & 0.0000058 \\
\hline 3 & 45.235 & 0.0545 & 0.0000581 & 0.000000153 & 0.0000032 \\
\hline 2 & 45.235 & 0.0364 & 0.0000354 & 0.000000057 & 0.0000013 \\
\hline 1 & 45.235 & 0.0182 & 0.0000135 & 0.000000008 & 0.0000002 \\
\hline & & 1.0000 & & 0.000004826 & 0.0000879 \\
\hline
\end{tabular}

Seismic Load Reduction Factor $(R)$ is 8. Spectrum Coefficient $S\left(T_{1}\right)$ and Spectral Acceleration Coefficient $A\left(T_{1}\right)$ are 1.219 and 0.488 , respectively. Total EEL $\left(V_{t}\right)$ was calculated as $270.5 \mathrm{t}$ and additional EEL $\left(\Delta F_{N}\right)$ was calculated as $20.3 \mathrm{t}$. According to TEC, these calculations and assumptions were used to check irregularities of the building. The controls of B2-weak-storey irregularity, relative storey displacements and second order effects (Tab. 4) provide that the coefficients are on safe side for $+Y$ direction. But, the control of A1-torsional irregularity provides safety for only the $1^{\text {st }}$ floor (Tab. 2). The controls for all irregularities provide that the coefficients are on safe side for $+X$ direction. To recover the building from torsional irregularity at $+Y$ direction, it is suggested that the shear walls should be constructed symmetrically and unsymmetrically at $+X$ and $+Y$ directions separately.

The best solution for preventing torsional irregularity was by constructing shear walls by two sides at outer axis of $+Y$ direction (Fig. 2b). The natural vibration period of 
the building is calculated as $0.727 \mathrm{~s}$. Spectrum Coefficient $S\left(T_{1}\right)$ and Spectral Acceleration Coefficient $A\left(T_{1}\right)$ are 2.143 and 0.857 , respectively. Total EEL $\left(V_{t}\right)$ was calculated as $583.1 \mathrm{t}$ and additional EEL $\left(\Delta F_{N}\right)$ was calculated as $43.7 \mathrm{t}$. According to TEC, the controls for all irregularities provide that the coefficients are on safe side for both $+X$ and $+Y$ directions (Tabs. 3 to 6 ).

Table 2 The calculation of A1-torsional irregularity coefficients (model without shear walls)

\begin{tabular}{|c|c|c|c|c|c|}
\hline Storey No. & $(\Delta i)_{\min }$ & $(\Delta i)_{\max }$ & $(\Delta i)_{\mathrm{ave}}$ & $(\Delta i)_{\max } /(\Delta i)_{\mathrm{ave}}$ & \\
\hline 10 & 0.00149 & 0.00276 & 0.00212 & 1.298 & $\mathbf{X}$ \\
\hline 9 & 0.00228 & 0.00393 & 0.00310 & 1.265 & $\mathbf{X}$ \\
\hline 8 & 0.00299 & 0.00496 & 0.00397 & 1.247 & $\mathbf{X}$ \\
\hline 7 & 0.00360 & 0.00586 & 0.00473 & 1.238 & $\mathbf{X}$ \\
\hline 6 & 0.00412 & 0.00661 & 0.00536 & 1.232 & $\mathbf{X}$ \\
\hline 5 & 0.00455 & 0.00720 & 0.00587 & 1.225 & $\mathbf{X}$ \\
\hline 4 & 0.00487 & 0.00761 & 0.00624 & 1.219 & $\mathbf{X}$ \\
\hline 3 & 0.00506 & 0.00780 & 0.00643 & 1.213 & $\mathbf{X}$ \\
\hline 2 & 0.00491 & 0.00738 & 0.00614 & 1.200 & $\mathbf{X}$ \\
\hline 1 & 0.00308 & 0.00444 & 0.00376 & 1.180 & $\mathbf{V}$ \\
\hline & & & & $<1.200$ & \\
\hline
\end{tabular}

Table 3 The calculation of B2-weak-storey irregularity coefficients (model with shear walls)

\begin{tabular}{|c|c|c|c|c|c|}
\hline Storey No. & $(\Delta i)_{\text {ave }}$ & $\eta_{k i}$ & & $\eta_{k i}$ & \\
\hline 10 & 0.002880 & 0.974 & & - & \\
\hline 9 & 0.002955 & 0.994 & $\checkmark$ & 1.026 & $\checkmark$ \\
\hline 8 & 0.002970 & 1.011 & $\checkmark$ & 1.005 & $\checkmark$ \\
\hline 7 & 0.002935 & 1.038 & $\checkmark$ & 0.988 & $\checkmark$ \\
\hline 6 & 0.002825 & 1.074 & $\checkmark$ & 0.962 & $\checkmark$ \\
\hline 5 & 0.002630 & 1.126 & $\checkmark$ & 0.930 & $\checkmark$ \\
\hline 4 & 0.002335 & 1.206 & $\checkmark$ & 0.887 & $\checkmark$ \\
\hline 3 & 0.001935 & 1.387 & $\checkmark$ & 0.828 & $\checkmark$ \\
\hline 2 & 0.001395 & 1.951 & $\checkmark$ & 0.720 & $\checkmark$ \\
\hline 1 & 0.000715 & - & & 0.512 & $\checkmark$ \\
\hline & & $<2$ & & $<2$ & \\
\hline
\end{tabular}

Table 4 The control of relative storey displacements (model with shear walls)

\begin{tabular}{|c|c|c|c|c|}
\hline Storey No. & $(\Delta i)_{\max }$ & $R .(\Delta i)_{\max }$ & $R .(\Delta i) \max / h_{i}$ & \\
\hline 0 & 0.003040 & 0.02128 & 0.00608 & $\checkmark$ \\
\hline 9 & 0.003100 & 0.02170 & 0.00620 & $\checkmark$ \\
\hline 8 & 0.003090 & 0.02163 & 0.00618 & $\checkmark$ \\
\hline 7 & 0.003040 & 0.02128 & 0.00608 & $\checkmark$ \\
\hline 6 & 0.002910 & 0.02037 & 0.00582 & $\checkmark$ \\
\hline 5 & 0.002690 & 0.01883 & 0.00538 & $\checkmark$ \\
\hline 4 & 0.002340 & 0.01638 & 0.00468 & $\checkmark$ \\
\hline 3 & 0.001920 & 0.01344 & 0.00384 & $\checkmark$ \\
\hline 2 & 0.001402 & 0.00981 & 0.00280 & $\checkmark$ \\
\hline 1 & 0.000738 & 0.00516 & 0.00147 & $\checkmark$ \\
\hline & & & $<0.02000$ & \\
\hline
\end{tabular}

Table $\mathbf{5}$ The control of second order effects (model with shear walls)

\begin{tabular}{|c|c|c|c|c|c|c|}
\hline Storey No. & $w_{i}$ & $\sum w_{i}$ & $(\Delta i)_{\text {ave }}$ & $V_{i}$ & $\theta_{i}$ & \\
\hline 10 & 476.16 & 476.16 & 0.002880 & 141.804 & 0.002763 & $\checkmark$ \\
\hline 9 & 476.16 & 952.32 & 0.002955 & 230.068 & 0.003495 & $\checkmark$ \\
\hline 8 & 476.16 & 1428.48 & 0.002970 & 308.524 & 0.003929 & $\checkmark$ \\
\hline 7 & 476.16 & 1904.64 & 0.002935 & 377.174 & 0.004235 & $\checkmark$ \\
\hline 6 & 476.16 & 2380.80 & 0.002825 & 436.016 & 0.004407 & $\checkmark$ \\
\hline 5 & 476.16 & 2856.96 & 0.002630 & 485.052 & 0.004426 & $\checkmark$ \\
\hline 4 & 476.16 & 3333.12 & 0.002335 & 524.280 & 0.004241 & $\checkmark$ \\
\hline 3 & 476.16 & 3809.28 & 0.001935 & 553.701 & 0.003803 & $\checkmark$ \\
\hline 2 & 476.16 & 4285.44 & 0.001395 & 573.315 & 0.002979 & $\checkmark$ \\
\hline 1 & 476.16 & 4761.60 & 0.000715 & 583.122 & 0.001668 & $\checkmark$ \\
\hline$\sum$ & 4761.6 & & & & $<0.1200$ & \\
\hline
\end{tabular}

Table 6 The calculation of A1-torsional irregularity coefficients (model with shear walls)

\begin{tabular}{|c|c|c|c|c|c|}
\hline Storey No. & $(\Delta i)_{\min }$ & $(\Delta i)_{\max }$ & $(\Delta i)_{\mathrm{ave}}$ & $(\Delta i)_{\max } /(\Delta i)_{\mathrm{ave}}$ & \\
\hline 10 & 0.002720 & 0.003040 & 0.002880 & 1.055 & $\checkmark$ \\
\hline 9 & 0.002810 & 0.003100 & 0.002955 & 1.049 & $\checkmark$ \\
\hline 8 & 0.002850 & 0.003090 & 0.002970 & 1.040 & $\checkmark$ \\
\hline 7 & 0.002830 & 0.003040 & 0.002935 & 1.035 & $\checkmark$ \\
\hline 6 & 0.002740 & 0.002910 & 0.002825 & 1.030 & $\checkmark$ \\
\hline 5 & 0.002570 & 0.002690 & 0.002630 & 1.022 & $\checkmark$ \\
\hline 4 & 0.002330 & 0.002340 & 0.002335 & 1.002 & $\checkmark$ \\
\hline 3 & 0.001950 & 0.001920 & 0.001935 & 0.992 & $\checkmark$ \\
\hline 2 & 0.001388 & 0.001402 & 0.001395 & 1.004 & $\checkmark$ \\
\hline 1 & 0.000692 & 0.000738 & 0.000715 & 1.032 & $\checkmark$ \\
\hline & & & & $<1.200$ & \\
\hline
\end{tabular}

\section{$4 \quad$ RESULTS AND DISCUSSION}

Torsional irregularity coefficients $\eta_{k i}$ with different positioned shear walls with the aim of strengthening rigidity of storeys were demonstrated in Figs. 3 to 6. The coefficients were calculated for each case (different positioned shear walls) and besides in both $+X$ and $+Y$ directions. According to results, single positioned shear walls at $+Y$ direction increased torsional irregularity coefficient, so irregularity for $+Y$ direction and coefficients is changing between $0.77-2.71$ (Fig. 3). According to the same case, the coefficients were not changing much more for $+X$ direction and the range is between 1.011-1.044 (Fig. 4). Also, the coefficients of symmetrical double positioned shear walls at $+Y$ direction are looking stable, not changing much more and the range is between 0.91-1.15 (Fig. 5). For the same case, but $+X$ direction, Fig. 6 demonstrates a decreasing trend against upper storeys; also the coefficients are decreasing from 1.051 to 1.001 .

The positioned shear walls at $+X$ direction and A-E axles have decreasing trend against upper storeys with values from 1.302 to 1.145 for $+Y$ direction controls, but most coefficients are bigger than critical value as 1.2. Contrary, the tendency is between $0.98-2.05$ by increasing trend bigger than 1.2 for $+X$ direction controls. Also, the coefficients of symmetrical double positioned shear walls at $+X$ direction are decreasing against upper storeys and the range is between 1.35-1.04. Finally, for the same case but $+Y$ direction control, the coefficients are changing between 1.147-1.621. The best model against earthquake loads is selected as outermost positioned at $+Y$ direction shear walls because torsional irregularity coefficients are smaller than 1.2 , safely.

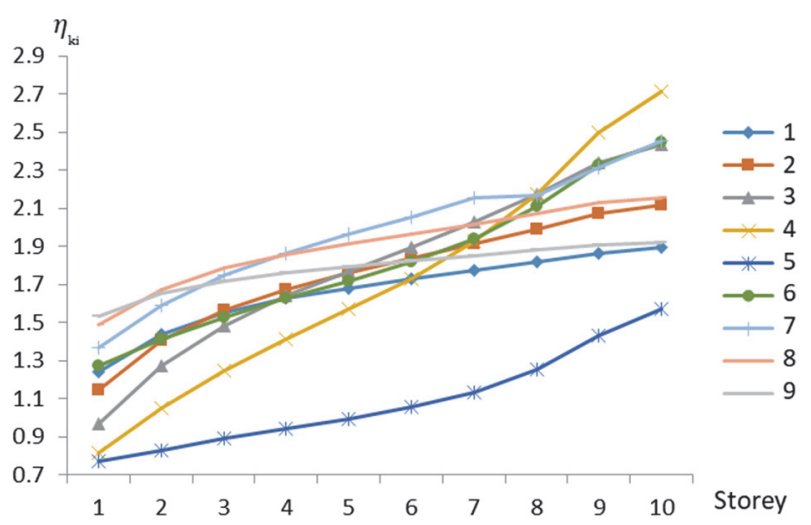

Figure $3 \eta_{k i}$ coefficients at storeys with different positioned (1-9 axles, $+Y$ direction) single shear wall for $+Y$ direction 


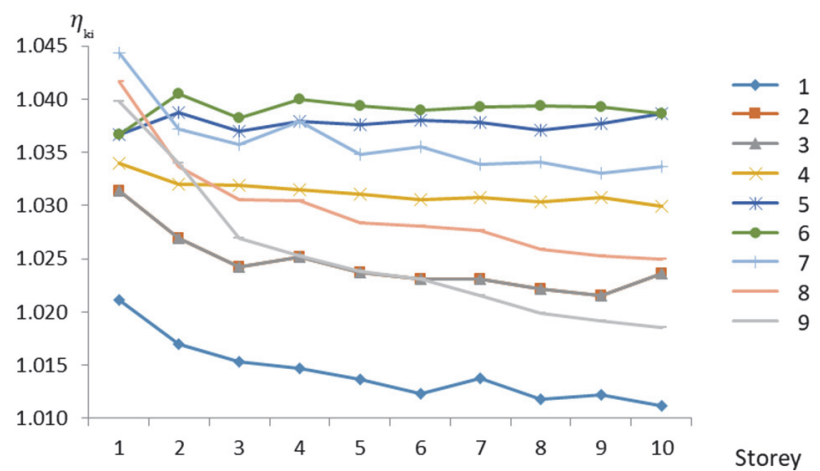

Figure $4 \eta_{k i}$ coefficients at storeys with different positioned (1-9 axles, $+Y$ direction) single shear wall for $+X$ direction
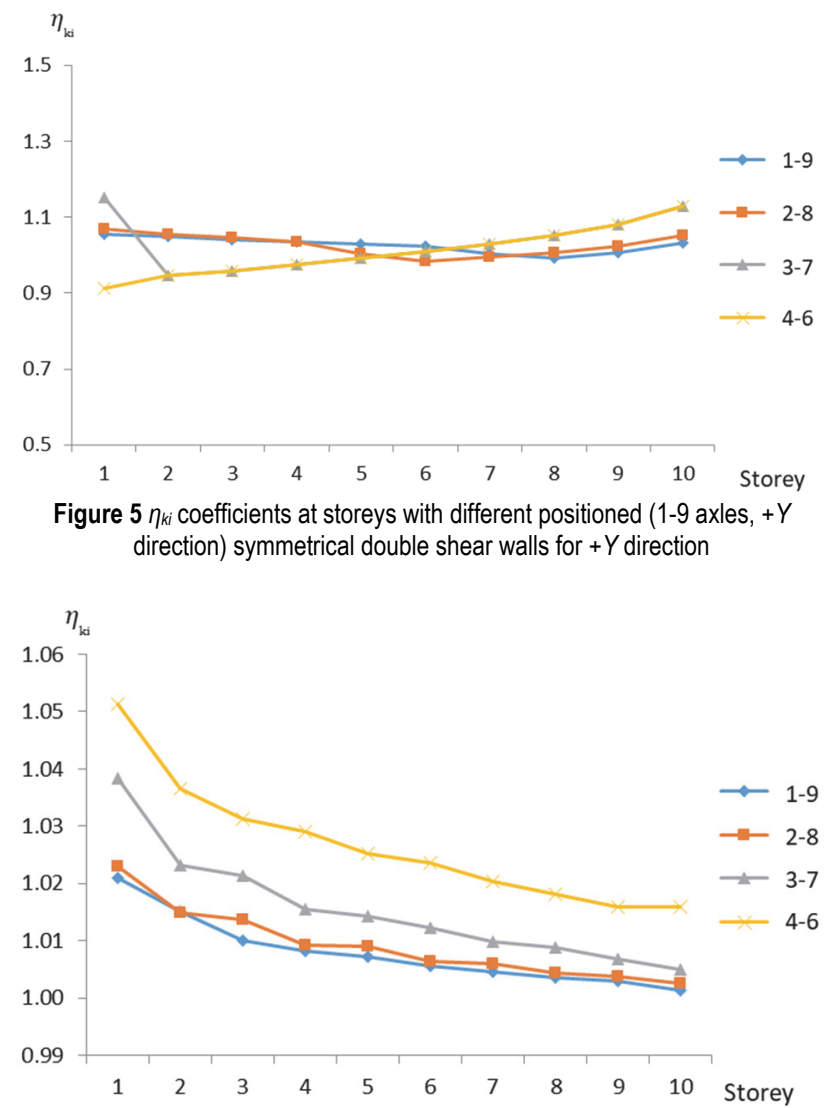

Figure $6 \eta_{k i}$ coefficients at storeys with different positioned (1-9 axles, $+Y$ direction) symmetrical double shear walls for $+X$ direction

\section{CONCLUSIONS}

In this study, all calculations and controls are based on TEC. The analyses were made according to location of shear walls and symmetrical or unsymmetrical shear walls. After the checks, the building model is safely provided to B2-weak-storey irregularity, relative storey routing and second order effects for $+X$ and $+Y$ directions. But there is A1 torsional irregularity at the building for $+Y$ direction. This problem was tried to be resolved by putting shear walls during analyses of shear walls; if single shear wall was put, the torsional irregularity was increased. But if symmetrical shear walls at $+Y$ direction were put, the torsional irregularity was decreased. As another test, when location of symmetrical shear walls was brought closer to rigidity center of the building, the torsional irregularity was increased again. In the same way, the same analyses were made for $+X$ direction. The torsional irregularity was increased every time, after putting single or symmetrical shear walls. Fundamentally as a result of this study, when symmetrical shear walls were put at outermost axles for longer part direction (for this study $+Y$ direction) at unsymmetrical buildings, the torsional irregularity problem can be solved.

The methodology and results give an insight to torsional irregularity in earthquake engineering. New studies on structural engineering can evaluate unsymmetrical buildings under different earthquake loads at any region in the world. There are similar earthquake codes in countries to make design considering irregularities of buildings.

\section{Acknowledgements}

This paper is prepared from graduation project course in Department of Civil Engineering, Cukurova University, Adana, Turkey.

\section{REFERENCES}

[1] Saetang, K., Srisawat, W., \& Dürrast, H. (2018). Crustal structures, geothermal sources and pathways beneath Northern Thailand revealed by local earthquake tomography. Chiang Mai Journal of Science, 45(1), 565-575.

[2] Dogan, M., Unluoglu, E., \& Ozbasaran, H. (2007). Earthquake failures of cantilever projections buildings. Engineering Failure Analysis, 14(8), 1458-1465. https://doi.org/10.1016/j.engfailanal.2007.01.008

[3] Gokdemir, H., Ozbasaran, H., Dogan, M., Unluoglu, E., \& Albayrak, U. (2013). Effects of torsional irregularity to structures during earthquakes. Engineering Failure Analysis, 35, 713-717. https://doi.org/10.1016/j.engfailanal.2013.06.028

[4] Tezcan, S. S. \& Alhan, C. (2001). Parametric analysis of irregular structures under seismic loading according to the new Turkish Earthquake Code. Engineering Structures, 23(6), 600-609. https://doi.org/10.1016/S0141-0296(00)00084-5

[5] Abd-Elhamed, A. \& Mahmoud, S. (2016). Nonlinear static analysis of reinforced concrete framed buildings - A case study on Cairo earthquake. Journal of Engineering Research, 4(4), 1-23.

[6] Hu, K., Yang, Y., Mu, S., \& Qu, G. (2012). Study on highrise structure with oblique columns by ETABS, SAP2000, MIDAS/gen and SATWE. Procedia Engineering, 31(2012), 474-480. https://doi.org/10.1016/j.proeng.2012.01.1054

[7] Acun, B. \& Sucuoglu, H. (2011). Evaluation of the Performance Limit States of Reinforced Concrete Columns in View of Experimental Observations. Teknik Dergi, 22(108), 5523-5541.

[8] Soyluk, A. \& Tuna, M. E. (2011). Effect of Seismic Base Isolation Usage on the Architectural Design of Irregular Buildings. Gazi Üniversitesi Mühendislik-Mimarlık Fakültesi Dergisi, 26(3), 635-642.

[9] Arslan, M. H.\& Gülay, F. G. (2006). A comparative study on strengthening applications of prefabricated buildings in earthquake regions. Arabian Journal for Science and Engineering, 31(1 C), 151-167.

[10] Chandler, A. M. \& Hutchinson, G. L. (1987). Evaluation of code torsional provisions by a time history approach. Earthquake Engineering \& Structural Dynamics, 15(4), 491516. https://doi.org/10.1002/eqe.4290150406

[11] Dutta, S. C., Das, P. K., \& Sengupta, P. (2017). Seismic Behaviour of Irregular Structures. Structural Engineering International, 27(4), 526-545. https://doi.org/10.2749/222137917X14881938989765

[12] Yildizlar, B., Akcay, C., \& Kemal Öztorun, N. (2018). A 
rapid analysis method for determining current status of existing buildings: A conceptual framework. Revista de La Construcción, 267-278. https://doi.org/10.7764/RDLC.17.2.267

[13] Sata, V., Wongsa, A., Somna, K., \& Chindaprasirt, P. (2016). Interfacial transition zone of pervious cement and geopolymer concrete containing crushed clay brick. Chiang Mai Journal of Science, 43(2), 402-408.

[14] Solakov, D., Simeonova, S., \& Christoskov, L. (2009). Seismic hazard maps for the new national building code of Bulgaria. Comptes Rendus de L'Academie Bulgare Des Sciences, 62(11), 1431-1438.

[15] Alecci, V., De Stefano, Galassi, S., Lapi, M., \& Orlando M. (2020). An assessment of American criterionfor detecting plan irregularity. In Seismic Behaviour and Design of Irregular and Complex Civil Structures III, 215-231. Springer, Cham. https://doi.org/10.1007/978-3-030-33532-8_18

[16] Ju, H., Lee, D., Kim, J. R., \& Kim, S. K. (2020). Maximum torsional reinforcement ratio of reinforced concrete beams. Structures, 23, 481-493. https://doi.org/10.1016/j.istruc.2019.09.007

[17] Dahmardeh, S. R., Motamedi, M., \& Aziminejad, A. (2020). A study on the effects of torsional component of groundmotions on seismic response of low- and mid-rise buildings. The Structural Design of Tall and Special Buildings, 29(4), e1699. https://doi.org/10.1002/tal.1699

[18] Hassan, W. M. (2020). Assessment of ASCE 7-16 seismic isolation bearing torsionaldisplacement. International Journal of Civil Engineering, 18(3), 351-360. https://doi.org/10.1007/s40999-019-00462-x

[19] Ugural, M. N., Giritli, H., \& Urbanski, M. (2020). Determinants of the turnover intention ofconstruction professionals: a mediation analysis. Sustainability, 12, 954. https://doi.org/10.3390/su12030954

[20] Arisoy, B. \& Arel, H. S. (2010). Performance Based Analysis of RC Buildings with Different Structural Properties. Gazi Üniversitesi Mühendislik-Mimarlık Fakültesi Dergisi, 25(3), 431-439.

[21] Ilki, A. \& Celep, Z. (2012) Earthquakes, Existing Buildings and Seismic Design Codes in Turkey. Arabian Journal for Science and Engineering, 37(2), 365-380. https://doi.org/10.1007/s13369-012-0183-8

[22] Khosravi, H., Shoaib Mousavi, S., \& Tadayonfar, G. (2017) Numerical study of seismic behavior of Composite Steel Plate Shear Walls with flat and corrugated plates. Revista de La Construcción, 16(2), 249-261. https://doi.org/10.7764/rdlc.16.2.249

[23] TEC (2007). Specification for Structures to be Built in Disaster Areas.

[24] Ozmen, G. (2004). Çok Katlı Yapılarda Aşırı Burulma Düzensizliği. Teknik Dergi, 15(71), 3131-3144.

[25] Vogwell, J. (1997). Predicting Failure in Non-Continuous Weld Seams When Used in Joints under Torsion Loading. Engineering Failure Analysis, 4(4), 227-236. https://doi.org/10.1016/S1350-6307(97)00026-5

\section{Contact information:}

Asst. Prof. Dr. Halil Ibrahim BURGAN

(Corresponding author)

Akdeniz University, Faculty of Engineering,

Department of Civil Engineering

07070, Konyaalti, Antalya, Turkey

E-mail: burgan@akdeniz.edu.tr 